\title{
Challenges in the Investment of ICT Infrastructure at Secondary School in Zambia, in Promoting Quality Education Delivery
}

\author{
Peggy Nsama, Margaret Mwale-Mkandawire, Sibeso Lisulo, Webster Hamweete and Simuyaba Eunifridah \\ Department of Educational Administration and Policy Studies, The University of Zambia, Zambia
}

\begin{abstract}
The Information and Communication Technology (ICT) industry has undergone unprecedented growth, making significant contribution to global trade and investment. Over the years, governments have developed plans to intensify investments in ICT in education. Most countries are now leveraging on the education and economic benefits on investing in ICT, as societies are increasingly gravitating from efficient to being knowledge based. This paper focuses on the challenges in investing in ICT infrastructure in secondary schools in promoting quality education delivery. Data was generated and gathered using a convergent parallel mixed-methods design, using questionnaires (Teachers: $\mathrm{N}=360$ ), semi-structured interviews (18 Ministry of Education Officials and 36 Head Teachers), Focus Group Discussions (324 pupils) and supplemented by document analysis. Participants were drawn from four provinces in Zambia: Lusaka, Copperbelt, Eastern and Luapula. The paper was anchored on The Theory of Capital Investment Appraisal Technique (CIAT). Quantitative data was analysed using SPPS using both descriptive and inferential statistics while qualitative data was subjected to thematic analysis.
\end{abstract}

The paper highlights significant challenges in ICT, among others: load-shedding of power in most schools; inadequate infrastructure, which compromised the input, process and output to education. Due to lack of specialised computer laboratories, some schools converted classrooms into computer laboratories. Hence, affecting the lifespan of the facilities. The study concludes that most of the challenges the country had were a result of lack of an investment criteria and strategy in ICT for schools, making it difficult to monitor or attract support from other stakeholders. Based on the findings and conclusions, the following recommendations were made: This study proposes an investment framework in ICT (ICTCIF), under the PPP approach (BOT Model), to invest in ICT in education. Which the Ministry of Education, with support from other stakeholders, should test and assess its potential benefit to the Zambian education system.

Key Words: Information and Communication Technology; Challenges; Public-Private-Partnership; Facilities; Investment.

\section{INTRODUCTION}

$\mathrm{I}^{\mathrm{r}}$ ndubitably, the unprecedented development of ICT has exerted demand on capacity building in infrastructure in both developed and developing countries. Consistently, ICT is perceived relevant in the promotion of sustainable development in education and other aspects in the $21 \mathrm{st}$ Century and having its main feature in the knowledge-based economy (Ramaswami and Sivarajan, 2002; Kaminow and Li, 2002; Butcher, 2010; Zhao and Jiang, 2013). In view of the foregoing, several studies have indicated the potential for ICT to transform education and other sectors of society (Hudson, 1997; Kozma, 2005; Chitkul, B., Mittoo, S., \& Bradley, M., 2006; Relly and Sabharwal, 2009). In agreement with this, Viitanen (2003) comments on the major role ICT plays in all aspects of national life. This includes such aspects as: politics, health, economic life and social cultural development, among others. Kinimäki, Vitanen and Vartra (2003) further relate ICT to a total transformation in perceptions and practices of conducting business, accessing information and services and in communication aspects, among others.

ICTs comprise a complex and heterogeneous set of goods, applications and services used to produce, distribute, process, and transform information. They include the outputs of industries as diverse as telecommunications, television and radio broadcasting, computer hardware and software, computer services and electronic media (such as the internet, electronic mail), commerce and computer games (Bennett, 2002). In augmentation, Antonelli (1992) and Pazi (2010) relate the role of ICT Infrastructure in political, social and economic development to "motorways in the fifties, electricity at the beginning of the century and railways in the nineteenth century". And the relevance of ICT infrastructure is observed in its use to "deliver ICT service where it is needed when it is needed, and in its most useful form" (Pazi, 2010).

ICT is a tool/strategy for the Teacher, not to replace a Teacher. Various authors have elucidated on the use of ICT as a pedagogical tool to aid the teacher in the teaching and learning process. Hence, enabling the teacher in the application of ICT facilities to alleviate the challenges in teaching, apart from provoking learners' capabilities in the acquisition of knowledge through ICT. Benefits of using ICT in teaching and learning include increased motivation in a learner, encouraged active participation and creativity, enhancement of knowledge and skills, ups one's responsibility and self-esteem and heightens collaborations among learners. In this regard, teachers have the mandate to appreciate information made available through ICT, in problem-solving, analysis and application of knowledge of ICT (Trucano, 2015; Ndibalema, 2014; Mdlongwa, 2012). 
The Zambian government through the Ministry of Education in Zambia (MOE) recognises the relevance of education, as a tool for poverty reduction and national development. The Ministry also realises effectiveness and efficiency of service delivery as a result of the limited investment in high school infrastructure, equipment, maintenance, teaching and learning materials, and in the supply of qualified personnel, at this level of education (Kangwa, 2012; GRZ, 2010). The National Implementation Framework (NIF) records an under-resource of Zambia's education system and fastidiously evinces very little investment in ICT in education. For example in 2010, 418 out of 8,493 Basic Schools countrywide had computers for teaching and learning, while only 634 had computers for administrative functions. These statistics were measured against pupil enrolment of $3,510,288$, bringing the pupil-tocomputer ratio to more than 8,000 pupils per computer (GRZ, 2010). Masaiti, Njobvu and Kakupa (2018) argued the centrality of ICT in the future of education in Zambia.

However, the Ministry of Education's strength had been revealed in its intention to ensure a successful remedy such as a robust network linking all Provincial Education Offices to its headquarters as well as other education institutions. These include the Examinations Council of Zambia (ECZ), Education Broadcasting Services (EBS), Bursaries Committee and Curriculum Development Centre (CDC) among others. Another strength lies in the fact that all the 14 colleges of education had ICT infrastructure connectivity and possessed fairly standard hardware and software infrastructure. The ministry also had a consolidated ICT Policy, implementation plan and ICT usage guidelines, as well as a complement of qualified staff to handle the ICT implementation plans (GRZ, 2010).

The Zambian education system has had challenges in ICT as highlighted by the MCT (2006), such as Tax on ICT procurement procedures that often lead to the acquisition of inferior materials, and the geographical coverage, which has been a severe impediment in the effective deployment of ICT due to costs and demand, among others. Masaiti (2018) also highlights challenges to ICT in Education related to integration and provision. On the basis of the above contextual background, this paper sought to identify and expound the challenges in the investment of ICT infrastructure at Secondary School level in promoting quality education delivery.

\section{THEORETICAL UNDERPINNING AND SELECTED LITERATURE}

This paper on challenges in the investment of ICT infrastructure at secondary school in promoting quality education delivery is guided by the Public Value Theory (PVT), which was invented by Harvard professor Mark H. Moore (1995). Public value theory was designed, in part, with a view to developing a set of ideas that provide an alternative to the ubiquitous influence of liberal economic reasoning in general and market failure criteria in particular (Bator, 1958).
Public values theory can be thought of as an effort to focus on some of the concerns of public interest theorists by formulating concepts and theories that strive for many of the same goals but with greater specificity. Though the current study focused on this conceptualisation, there are other models that are utilised to invest in ICT, one of them being the Capital Investment Appraisal Technique (CIAT). However, in spite of the significant role this and other models play on investment aspects, this study does not use them to analyse the Zambian scenario, given the infancy of the country's capitalization structure, especially in ICT. This is evidenced by the current scenario where a substantial number of public services in Zambia are manual based (Chipeta, 2018). However, future research should test this or other investment models when all the facilities are put in place in ICT in Zambia's schools.

Zambia, like many developing countries, has been faced with serious challenges in investing in ICT, which drives the country by a great distance from exploiting the potential that is embedded in ICT towards growth (Chaamwe, 2017). The Public Value Theory (PVT) in this case supports the creation of public value by influencing policy in the Zambian education system. Despite being in its infancy, Zambia has made some efforts to formulate policy that supports investment in ICT, so as to create value for the citizenry. However, the policy that is available, specifically in education, is still in draft form and so lacks the authenticity or authority to provoke implementation to the maximum. The Public Value comes in handy to provoke the legitimacy and support of the policy, which places a demand on the Government to consider passing the draft policy on ICT in education through Parliament for it to be enacted as a bill. Legitimacy in this case implies support from the community as well as the authorities under which it is to be implemented. The demand from the theory is that for public value to be created in education using ICT, there has to be democratic legitimacy in the plan of implementing the curriculum that is presently in schools, where ICT is to be offered as a subject.

For a country aspiring to invest in ICT architecture, both opportunities and challenges are unavoidable. The onus is on the country to identify both aspects and strategically plan to attain the apex of its goals in the investment in ICT architecture. Ang'ondi (2010) highlights opportunities that are as a result of investment in ICT, especially the development of policy, which has standardised procedures. The procedures set by various governments have, in some cases, attracted donors. Investment in ICT architecture offers an opportunity for the Government of Zambia to formulate policy that will cater for the needy areas in education, particularly secondary schools. Consistently, the effort to invest in ICT provokes policy that caters for issues to do with management and maintenance of ICT infrastructure as well as the utilisation of this infrastructure by the end users.

However, challenges in investing in ICT include inaccurate records to trace and cost the investments being done against 
the outcomes (Wamakote, 2010). Other challenges, which Zambia is equally identified with, include: lack of access to appropriate ICT equipment, lack of reliable equipment and lack of technical, administrative and institutional support in some countries; lack of a clear vision by government and failure of governmental bodies to cooperate. Uneven levels of awareness of the relevance attached to ICT especially in national strategies. Apart from that, high software piracy rates resulting in jeopardised confidence, no common plan whose result is compromised ICT efficiency and opportunities, telecommunication deregulation (slow and limited). More also, there is the aspect of digital poverty which is exhibited by mediocre bandwidth and connectivity as well as poor interconnectivity of Internet Protocol (IP) systems, digital divide, among others, especially the remote areas of the country (Agboh, 2015; Mulima, 2013; Ramli, 2012; Dutta and Coury, 2002).

It should be noted that most of the challenges highlighted affect not only Zambia but other developing countries as well. These challenges account for the need for the Government to concentrate its efforts in investing in ICT infrastructure, especially in remote areas. The outcomes of these efforts would be evident and contribute to development.In spite of the challenges, Zambia among other countries, has made some efforts to invest in ICT education in various aspects, though in a very insignificant way. However, it is equally in the category of other African countries whose national policy has not yet been authentic as the existing policy is still in draft form and still needs to be passed in parliament as a bill.

\section{The Problem and Question Guiding the Research Paper}

Globally, rapid developments in information and communication technologies (ICTs) in recent years have resulted in significant changes in the way the world operates and communicates. Subsequently, this has had an impact on educational and training needs, both in terms of the content and the delivery of educational and training services (Esoswo, 2011). To a considerable extent, the introduction of Information and Communication Technology in Zambian schools has enormously contributed to universal access to education, equity in education, the delivery of quality learning and teaching, teachers' professional development and more efficient education management, governance and administration (Phiri, 2016). However, despite the enormous contributions, the investment of ICT infrastructure at secondary school in promoting quality education delivery has subsided with numerous challenges. In Zambia, limited studies have been explicitly done to unearth the challenges in the investment of ICT infrastructure at secondary school in promoting quality education delivery. This study therefore sought to identify and expound the challenges in the investment of ICT infrastructure at secondary school in promoting quality education delivery. More specifically the study answers one question:
1. What are the challenges in the investment of ICT infrastructure at Secondary School level in promoting quality education delivery?

\section{METHODOLOGY AND DESIGN EMPLOYED}

As regards the methodological approach, the paper employed the Mixed Methods Design, which is defined as "a procedure for collecting, analysing and mixing both quantitative and qualitative methods in a single study or a series of studies to understand a research problem" (Creswell and Clark, 2011). Creswell (2012) assumes better comprehension of the utilisation of both approaches to the issue being investigated and questioned, than separating the two approaches. This approach enables a researcher to have a comprehension of both quantitative and qualitative research so as to maximise the benefits of this combination (Creswell, 2012; Ishida et al, 2012; Nsama, 2008). He encourages the use of mixed methods when a researcher has both quantitative and qualitative data, based on the understanding that both of them offer a better comprehension of the research problem being investigated. Besides that, Creswell (2012) also encourages the use of mixed methods when one category of research is inadequate to respond to the research problem at hand, or address the research questions.

This study employed the Convergent Parallel Design, which requires the researcher to generate and gather both quantitative and qualitative data simultaneously and both types of data carry equal weight. As alluded to earlier, Bryman (2016) refers to these approaches (quantitative and qualitative approaches) as paradigms. The researcher used this approach to generate and collect data so as to enhance the sufficiency of the data to encapsulate and divulge data required to manifest the investment in ICT architecture in Zambian secondary schools, by examining infrastructure and policy. This approach to research was chosen as it offers a greater strength in the output in relation to either qualitative or quantitative research only. It goes beyond the science of data collection and analysis of both kinds of data. This approach instead has both qualitative and quantitative approaches used in tandem (Creswell, 2012).

The study included Government, Grant-Aided and Private secondary schools in Lusaka, Eastern, Copperbelt and Luapula provinces of Zambia. In this regard, this study consisted of a population from different departments and ministries of the Government of Zambia and Secondary Schools in four out of the ten provinces of Zambia, namely: Eastern; Copperbelt; Luapula; and Lusaka provinces, as mentioned earlier. The selection of these provinces was on the basis of the two of them, Copperbelt and Lusaka, having more urban districts than rural, whereas Eastern and Luapula were selected on account of having more rural districts than urban, which would grant evident grounds for generalisation. Out of the selected provinces, three districts were selected purposively, on the basis of having three types of secondary schools, that is: Government; Grant-Aided and Private. While 
the Government and private schools were selected randomly, the grant-aided schools were selected purposively, on the basis of being a rural school so as to allow for establishment of availability of ICT equipment on account of being rural grant-aided schools.

The sample in this study comprised a total 738 participants broken down as follows: 324 pupils, 360 teachers and 36 head teachers from all the selected schools. This implied 8 pupils, 10 teachers and 1 head teacher from each of the selected schools. A total of 18 Ministry of Education officials were selected: two officers from the MOE Headquarters on the basis of their ICT specialty. The same criterion was applied in the selection of one (1) officer from each Provincial Education Office as well as each District Education Standards Office in the selected districts. A total of 36 schools were selected, which implied a selection of three (3) secondary schools from each of the selected 12 districts.

The study employed different techniques to select the samples so as to ensure non-bias of the outcomes as a result of the respondents' sentiments. Teachers and pupils were selected randomly, using the simple random sampling procedure and in some few cases using convenience sampling. Convenience sampling is a type non-probability sampling where a sample is selected on account of being available to the researcher (Bryman, 2016). The Convenience sampling technique was used in very few situations, where there were very few teachers in a school, therefore, posing a challenge to using the simple random sampling or probability sampling techniques. Head teachers were automatically considered by virtue of their administrative role in the school and being the overall leader of their school, from each of the schools selected. Ministry of Education officials were selected purposively, on the basis of their closeness to ICT projects or similar responsibility. Purposive sampling is a form of nonprobability sampling in which a researcher targets to select members of the sample in strategic manner (Kakunta et al, 2020; Kapembwa et al, 2020; Bryman, 2016; Nkosha et al, 2013). The selected participants should be relevant to the research questions that have been asked in the study.

This study employed a questionnaire that incorporated a fivepoint Likert scale questions and or items. The questionnaires were administered to teachers. Ten teachers per school were selected to answer to the questionnaire. Qualitatively, the researcher carried out interviews with Ministry of Education officials starting from the Ministry of Education Headquarters, through to the Provincial Education Officers, as well as the District Education officers. These were officers who were close to ICT issues in the education sector. Apart from that, interviews were also conducted with Head Teachers for each of the selected schools. A timetable was set for the interview appointments in the various sites. Additionally, a focus group discussion guide was used to interview pupils on the investment in ICT architecture in secondary schools in Zambia, with particular focus on infrastructure and policy. The focus group discussions were to confirm the validity of the findings from the questionnaire, and this also validates the relevance of triangulation in research.

Information collected using the teachers "questionnaire were analysed using descriptive statistical approaches, in which percentages, means, standard deviation, among others, were derived where appropriate. Inferential statistics were also derived and utilised for further analysis of the data. As for open ended questions, the participants 'responses were coded into categories and the frequency of their responses in each category was resolved for analysis using the quantitative strategy. For coded data, discrete data analysis was used and frequency tables, percentages, and other statistical computations were derived, using the Statistical Package for Social Sciences (SPSS). According to Bryman (2008), the SPSS software is the most widely used computer software for the analysis of quantitative data for social scientists.

In qualitative research thematic analysis was used in order to identify major concepts or themes. Thematic analysis involves familiarising oneself with the available data (Braun and Clarke, 2006). In an effort to analyse interviews and focus group discussions (group interviews), the researcher had to listen to the audio recordings in both aspects repeatedly in order to transcribe the information into verbatims. Not only that, the researcher also had to read and re-read through the transcripts so as to recognise emerging themes that would be helpful to answer the research questions of the study. Information that had high frequency had a higher repetition in driving the point as this was an indication of the critical areas of need in line with investment in ICT infrastructure in secondary schools as well as policy.

\section{RESULTS}

Challenges in the investment of ICT infrastructure at secondary school in promoting quality education delivery

\section{Challenges in ICT Facilities}

In an effort to establish challenges in investment in ICT infrastructure, a cross-tabulation computation was conducted (Table 1). The aim of the cross-tabulation was to establish whether the challenges were due to a school being a grantaided or private or Government school, or a school being rural or urban located. In addition, the cross-tabulation was used to establish whether the perception of the challenges was due to one being female or male or whether because a teacher was trained in ICT or not trained. The cross-tabulations were computed by gender, type of school, school location, work experience, educational level and a teacher being trained in ICT or not.

Table 1 shows perceptions of teachers on the challenges of investment in ICT infrastructure in general terms, as well as stratified by six variables: gender, type of school, school location, work experience, educational level and whether teachers were trained in ICT or not, using frequencies and corresponding percentages. Based on the teachers' perceptions 
in this table, the challenge rating of the items revealed that investment in ICT infrastructure had a 'poor' rating in majority of the responses. Generally the 'poor' rating was $(285,79.2 \%)$ and the rating by variables had the highest in teachers in urban location $(185,64.9 \%)$ followed by teachers who were not trained in ICT $(183,64.2 \%)$. The third was teachers from the male gender $(174,61.1 \%)$. Although ratings were recorded in the 'good' and 'excellent measure, the outcomes were to a minimum in all aspects.

Table 1: Teachers Perception on Challenges in Investment in ICT Infrastructure by Variables

\begin{tabular}{|c|c|c|c|}
\hline \multirow[b]{2}{*}{ Parameter } & \multicolumn{3}{|c|}{ Challenges in ICT Infrastructure } \\
\hline & Poor & Good & Excellent \\
\hline $\begin{array}{c}\text { General } \\
\text { Perception }\end{array}$ & $285(79.2)$ & $55(15.3)$ & $20(5.6)$ \\
\hline \multicolumn{4}{|l|}{ Gender } \\
\hline Male & $174(61.1)$ & $28(50.9)$ & $12(60.0)$ \\
\hline Female & 111(38.9) & $27(49.1)$ & $8(40.0)$ \\
\hline \multicolumn{4}{|l|}{ Type of school } \\
\hline Government & $103(36.1)$ & $17(30.9)$ & $0(0.0)$ \\
\hline grant-aided & $94(33.0)$ & $19(34.5)$ & $6(30.0)$ \\
\hline Private & $88(30.9)$ & $19(34.5)$ & $14(70.0)$ \\
\hline \multicolumn{4}{|l|}{ School Location } \\
\hline Rural & $100(35.1)$ & $15(27.3)$ & $4(20.0)$ \\
\hline Urban & $185(64.9)$ & $40(72.7)$ & $16(80.0)$ \\
\hline \multicolumn{4}{|l|}{ Work experience } \\
\hline$<1$ year & $47(16.5)$ & $10(18.2)$ & $0(0.0)$ \\
\hline $1-5$ years & $102(35.8)$ & $29(52.7)$ & $9(45.0)$ \\
\hline $6-10$ years & $81(28.4)$ & $7(12.7)$ & $7(35.0)$ \\
\hline$>10$ years & $55(19.3)$ & $9(16.4)$ & $4(20.0)$ \\
\hline \multicolumn{4}{|l|}{ Educational level } \\
\hline Diploma or below & $157(55.1)$ & $35(63.6)$ & $9(45.0)$ \\
\hline Degree or higher & $128(44.9)$ & $20(36.4)$ & $11(55.0)$ \\
\hline \multicolumn{4}{|l|}{ Trained in ICT } \\
\hline Yes & $102(35.8)$ & $19(34.5)$ & $6(30.0)$ \\
\hline No & $183(64.2)$ & $36(65.5)$ & $14(70.0)$ \\
\hline
\end{tabular}

*Data is presented as frequency with corresponding percentage in parenthesis

One of the challenges relating to the interviewees' responses had to do with a lack of well-designed computer laboratories. One Ministry of Education Official made a critical remark to this effect, as:

A good number of schools have what they call computer laboratories but majority of them are not specialised rooms and therefore, not conducive for a long-term use and storage of computers (Transcript 2).

Overwhelmingly, the response by the officers, when asked to describe the access to ICT facilities by upper secondary schools, such as internet, was negative. All the 18 officers described the access as being poor and, in some cases, schools had no many ICT facilities, especially internet access. In some schools where the internet was available, pupils had no legal authority to use it as it was restricted to members of staff only. Examples are revealed by Ministry of Education officials who commented:

Access to internet facilities in upper secondary schools is poor because most schools have limited materials which are not enough for both teachers and learners during lessons and practicals (Transcript 13).

Internet services are paid by the schools whilst others do not have access to internet due to financial challenges .... In some schools where internet is connected, learners are not allowed unless under close supervision and monitoring due to cybercrimes and internet sites which are not good for them (Transcript 6).

The limitation or restriction in accessing ICT facilities either on the part of teachers or learners poses a serious challenge in the maximisation of the benefits of ICT in schools as the freedom is denied of the teachers and learners, who are supposed to be exposed to ICT as and when they need to. In this case, limiting the acquisition of knowledge and the skills in ICT.

When asked how many pupils used a computer during computer lessons, the pupils from different schools indicated that some of them - between 3 to 5 pupils - were using 1 computer. Some of them indicated that in their schools 2 pupils used one computer, others had 1 pupil use 1 computer and very few mentioned more than 5 pupils using 1 computer. While these responses create an impression as though the ratio of pupils to computers is low, the responses in this question clarify the foregoing. As some pupils clarified:

In our school, not all pupils learn computers, only junior secondary section takes the computer lessons, although even at that level, the subject is not compulsory in some schools. Some private schools offer optional computer lessons at senior secondary but, in our case as a Government school at junior level, it is a compulsory subject and senior level, this is when it has been introduced as an optional subject because all these years beginning 2013 there has not been computer studies at senior level, it is only now because of not having enough computers to carter for all the classes (Focus Group Discussion with Pupils, March 2017).

Most of the learners revealed the challenge of inadequate learning materials, other challenges regarding computers 
included: inadequate computers, limited human resource in ICT, load shedding, ignorance in computer utilisation, unrepaired malfunctioning computers and also inadequate parts for computer hardware, such as keyboards. At one school, pupils asserted:

We do not have adequate learning materials in ICT. We only have one teacher for ICT. Our school faces challenges like when it comes to writing exams in ICT in that we receive other pupils from other schools to come and write from our school because other schools have no facilities to write exams, hence, they are unregistered for ICT exams (Focus Group Discussion with Pupils, March 2017).

\section{Inferential Analysis of Teacher Perception on Challenges of Investment in ICT Infrastructure}

A Mann-Whitney U Test was conducted to test the null hypothesis (at alpha $=0.05$ ) that challenges in investment in ICT facilities was not depended on the location of the school that is rural or urban (Table 2). Median scores of participants from rural schools and participants from urban schools were 172.44 and 184.48 , respectively. There was no significant difference in the challenges in investment in ICT facilities between the two groups (Mann-Whitney $\mathrm{U}=13909.5, \mathrm{Z}=$ $0.463, \mathrm{p}=0.643$ two-tailed). Therefore, the null hypothesis was accepted.

A Kruskal Wallis test was conducted to test the null hypothesis (at alpha $=0.05$ ), that availability of ICT facilities was not dependent upon the type of the school of the respondents (Table 2). The results show enough evidence why the null hypotheses should be accepted $\chi^{2}(2)=2.25772$, $\mathrm{p}=0.283$. This therefore, suggests that the challenges in investment in ICT facilities were not depended on the type of school.

Table 2: Statistics for Teacher Perception of Challenges in Investment in ICT Infrastructure

\begin{tabular}{|c|c|c|c|c|}
\hline & \multicolumn{4}{|c|}{ Challenges of Investment in ICT Infrastructure } \\
\hline $\begin{array}{c}\text { Demographic } \\
\text { Variable }\end{array}$ & $\begin{array}{c}\text { Chi- } \\
\text { Square } \\
(\chi 2)\end{array}$ & Df & $\begin{array}{c}P \\
\text { Value }\end{array}$ & Comment \\
\hline $\begin{array}{c}\text { Type of } \\
\text { School }\end{array}$ & 5.236204 & 2 & 0.073 & $\begin{array}{c}\text { No Significant } \\
\text { Difference }\end{array}$ \\
\hline & \multicolumn{2}{|c|}{ Challenges in Investment in ICT Infrastructure } \\
\hline $\begin{array}{c}\text { Demographic } \\
\text { Variable }\end{array}$ & $\begin{array}{c}\text { Mann- } \\
\text { Whitney } \\
\mathrm{U}\end{array}$ & $\mathrm{Z}$ & $\begin{array}{c}P \\
\text { Value }\end{array}$ & Comment \\
\hline $\begin{array}{c}\text { School } \\
\text { Location }\end{array}$ & 13380 & - & 0.301 & $\begin{array}{c}\text { No Significant } \\
\text { Difference }\end{array}$ \\
\hline
\end{tabular}

Note. * indicates $p<0.05$; ** indicates $p<0.01$

The study also established that from the introduction of ICT in schools, most of the schools were left and expected to accomplish certain aspects or requirements of ICT by themselves. For example, in schools where the policy was utilised to some level, some schools had become 'selfsustained in ICT', and had to provide ICT materials themselves. Besides that, some schools were also responsible for repairs of the ICT facilities as well as training of teachers and sourcing of funds. Evidence to these finding are statistics in Table 1, which record the highest poor rating in investment by Government in computer hardware and peripherals poor rating at $342(95.0 \%)$; computer software poor rating 320 $(88.9 \%)$; internet and other multimedia platforms poor rating at $355(98.6 \%)$; support and services poor rating $318(88.3 \%)$; telecommunications and supporting infrastructure poor rating $285(79.2 \%)$ and physical infrastructure poor rating 283 $(78.6 \%)$.

\section{DISCUSSION}

With regards to the challenges in relation with ICT infrastructure, most participants acknowledged taking good care of and maintaining the available ICT facilities in their schools. Although some schools had challenges to quickly repair broken down ICT facilities due to financial challenges. In spite of some schools not being affected by frequent breakdown of the facilities, this scenario was dependent on the type of school that is Government, Grant-Aided and Private. The findings are confirmed by teachers' responses regarding support and services to schools by Government and stakeholders in Table 1. Where the majority responses were rated the highest as being poor across the 6 variables: gender, type of school, school location, teachers' work experience, teacher educational level and teacher training in ICT. As shown in Table 1, the highest 'poor' rating of all the variables was teachers in urban locations with 214 (67.3\%) and 205 $(67.0 \%)$ in both aspects, followed by those from teachers who were not trained in ICT $(213,67.0 \% ; 199,65.0 \%$ respectively) and third being the male gender with 191 (60.1\%) and 178 $(58.2 \%)$ respectively.

The findings of the study also clearly established that most ICT facilities in secondary schools were not adequately available to carter for everyone in most schools. The findings revealed that the majority rating 'poor' on the teachers' general perception of the availability of ICT facilities with rating $261(72.5 \%)$. These were similar to the findings by various variables: gender, type of school, school location, work experience, educational level and whether teachers were trained in ICT or not. The commonest facilities that were easily accessible by administrators, teachers and pupils in schools, as reported by the participants, where facilities were available, were desktop computers as well as computer laboratories, of which most of them were converted from ordinary classrooms. While in some schools computer to pupil ratio was very high, other schools had a lower ratio, especially in Grant-Aided and Private schools. Some pupils from these schools mentioned that they had 3 to 5 pupils using 1 computer and some also had 2 pupils using one computer, and in very exceptional cases some of these schools had 1 pupil using 1 computer. In most cases, not all pupils were learning ICT subject. Most pupils revealed that only junior classes (Grades 8 and 9) took the ICT subject as a compulsory subject and some had the subject at senior secondary where pupils took it as an option. This accounts for some schools having 
the lower ratio of computer to pupils, and not necessarily that most of such schools had a lot of computers.

The challenge of poorly equipped and non-existing ICT infrastructure has drawn the attention of various researchers, whose end result has been advocacy for escalated infrastructure evolutions and such effort need to be amidst precedence. These should top financial plans that are indispensable for schools to reach expeditious evolutions as well as upgrades in other ICT aspects such as hardware, software and networks (Anne, Nang'undaKukali, 2013). A report from INE (2014) expresses a transformation that occurs when deliberate programmes are set and launched that affect the whole nation. Such programmes provoke various key players to the education system to focus and apply concerted efforts on similar goals and activities. Such inputs have substantial advancement as their greatest end result, in the computing equipment supplied for teaching and learning pursuits in institutions of learning. Such initiatives also have a great influence on the average number of students per computer, in most cases, the ratio decreases (INE, 2014).

Sentiments by Nsama et al (2020) and Serpell (2014) raise a concern for the current scenario in Zambian schools. Serpell (2014) annotates, "many of the challenges facing the Zambian society revolve around a felt need for broader and more equitable distribution of resources: not only material wealth and political power, but also knowledge". The inadequate facilities pose a great challenge for Zambia to answer to the need for equal access to resources for pupils, so as to enhance knowledge acquisition by pupils (Nsama et al, 2020). According to Peter Wallet (2015), pupil-to-computer ratio in Zambia was recorded to be at 145 to 1 in 2015 . This possess a challenge on the Zambian education system as an adequate number of computers or other ICT facilities means easier and effective access to ICT facilities by learners (UNESCO, 2014).

These findings are consistent with sentiments of various researchers, who have identified challenges in the integration of ICT as being lack of electricity, internet connection and poor or non-existence of technology facilities. This scenario demands that schools, through their states, "should have programmes of technology refresh, renewals or some other programmes of updating equipment once it is no longer secure, economically viable to support or no longer meets the needs of the users" (Lockwood and Cornell, 2013:16; Syomwene, 2017b). Shaikh and khoja (2011), state that the inadequacy of ICT facilities account for the fewer computers compared to the number of pupils in a particular school. It must be noted that Zambia is not the only country faced with such challenges, but an issue affecting most developing countries (Jain and Akakandelwa, 2016). This is due to massive growth in enrollment, and other issues that include infrastructure challenges, incorrectly perceiving ICT as a problem for organisational transformation, not making ICT responsive to the organisational vision and mission, and developing non-systematic methods of implementation of ICT
(World Bank, 2009B; Tomkinson et al, 2006; Tusubira and Mulira, 2004).

Castillo (2017) remarks that the critical and vital factors that guarantee for a successful and viable incorporation of ICT include: access to ICT facilities, leadership inventiveness in ICT utilisation and teacher training. In agreement with that, Khumalo et al (2015) and Adeosun (2010) underscore that deficient equipping of ICT infrastructure, as well as insufficient or absence of other ICT facilities such as electricity, educational resources (for example school computers), access to internet, among others have adverse influence on teaching and learning, especially science subjects. Gil Flores et al (2017) remark that an internet connection hastens access to information and materials at one's disposal on platforms created for educational motives.

Though most schools in Zambia were connected to the major power supply company called the Zambia Electricity Supply Corporation (ZESCO), which appeared to be an advantage for most schools, in the actual sense it was not. The study established that most of the schools were affected by the loadshedding exercise, which went for very long hours and majority of the affected schools had no alternative power source. Such an atmosphere for most schools becomes a serious challenge. No matter how much schools want to maximise the benefits of ICT, as long as schools have no source of power all their plans are very far from being executed.

This scenario relates to the study by Olibie and Akudolu (2009:2), who established the non-use of the computers schools received in Nigeria, due to the challenge of load shedding. In the researchers' informal interactions with some of the principals and teachers of the selected schools, researchers established that, the computers these schools received were not utilised at all, in academic or administrative activities, due to: lack of electricity, inadequate space, leaking roofs and broken windows in the locations where the computers could have been kept. And also others attributed their challenge to inadequate security for the computers and lack of technical support. UNESCO (2014) describes the awkwardness of executing ICT in education if power supply is intermittent in national infrastructure. In the face of continuous advancement in ICT, unstable electricity becomes a constraint in the successful implementation of facilities such as projector, computer, video streaming, and television, among others. Such facilities demand consistent energy sources to brace ICT in education (Muhammad and Daura, 2017; Siddiquah and Salim, 2017).

The challenge of poorly equipped and non-existing ICT facilities or infrastructure compromises the privileges which pupils need to have in the education expectations. The Public Value Theory becomes relevant in this respect as the richer the education environment, the higher the value that is placed on it. What makes the education environment rich and richer is the availability of facilities and the adequate supply of 
facilities. The more the public is satisfied with what education can offer, the more the public value (Moore, 1995; Borgonovi, 2005; Talbot, 2006). With the global influence of ICT on education, the more ICT facilities the education system offers, the more citizens place value on education. Public value in the case of ICT is about the generation of opportunities for contemporary manifestation of knowledge as well as comprehension which were very difficult to acquire or did not exist (Lennon and Berg-Cross, 2010). However, the scenario in the Zambian secondary schools does not offer anything better than a demotivating environment. For example, having ICT an optional subject or the challenge of load shedding, such aspects lead to a compromised education scenario in the education system. Thereby, compromising or reducing the public value.

The study has shown that though some participants, such as pupils in the focus group discussion mentioned having very few computers, they related the few facilities to various uses in the school. The uses for these computers included lessons, which also include practical lessons, actual lessons and class exercises. They also revealed that mostly their teachers also used the computers to prepare lessons as well as assessments. The pupils also mentioned the use the computers by their teachers to prepare timetables, conducting research and compiling results for pupils. Apart from that, the computers were also used during examinations and tests. Further, the findings reveal poor use of the facilities as the highest rated with $232(64.4 \%)$. This was the scenario in relation with various variables such as: gender, type of school, school location, teachers work experience, teacher education level and whether teachers were trained in ICT or not.

Consistent with these findings, many authors have attributed the use of ICT by teachers to characteristics such as: experience and skill, the grade that is taught, age, gender, academic department, teachers' commitment, their viewpoint towards ICT, their attentiveness to special education and health with reference to ICT, personality advantage, in ICT use (Rohatgi et al, 2016; Bas et al 2016; Scherer et al, 2015; Kreijns et al, 2013; Suarez et al, 2012; Van Braak, 2001; Akbulut, 2009; Koehler and Mishra, 2009; Tondeur et al, 2008; Li, 2008, Ertmer, Ottenbreit-Leftwich and York, 2007; Anderson and Maninger, 2007; Fraizer and Bailey, 2004). Other traits of teachers include: their confidence with respect to the utilisation of technology, their kind of employment of technology, their procedural propositions that are oriented with constructivism and their team spirit in implementing ICT (Bas et al, 2016; Bai et al, 2016; Petko, 2012; Prestige, 2012; Bingimlas, 2009; Tondeur et al, 2008; Wong and Li, 2008; Koehler and Mishra, 2005). Akbulut (2009) also designates learning group policies as being components that are analogous with ICT utilisation. Apart from that, leadership traits are also regarded as being cardinal for the use of ICT in education (Pelgrum and Voogt, 2009). While teachers are the principal agents of transformation and propagation of expertise and schemes at the school level, head teachers play a very significant role to the success of these efforts (Njoroge and Kibaru, 2012). School managers have a critical mandate of ensuring an atmosphere in the school that will enhance effectual and successful teaching and learning. And ensure effective management of personnel and financial assets (Kogei, 2017). Gil-Flores et al (2017) identified two levels of ICT utilisation by teachers, the first being the ineffective use. The ineffective use included aspects such as fundamental pillars for teachers, which frequently necessitates the use in class preparation. The second level is one which necessitates the utilisation of ICT as an educational asset in the teachers' everyday assignments with learners. Supporting this, Afshari et al (2012) advise all school managers and teachers in schools to enhance their competence in ICT utilisation and ensure effective application of ICT facilities in their daily routines.

The results in this study by gender were the opposite of the findings by Scherer et al (2015), who established the use of ICT to be greater among male than female teachers, these male teachers were moderately young. The teachers also were teaching the highest grades. However, the outcomes of these variables were miniature and their statistical significance was only by age and gender (Scherer et al, 2015: Suarez et al, 2012; Van Braak, 2001). Consistently, Tondeur et al (2008) comment that the influence of variables such as gender, age and others, is very minimal in relation to other factors, such as openness to change pertinent school policies.

In spite of most schools being 'poorly equipped' or affected by 'non-existence of ICT facilities', this study established that for the schools that had some facilities most of them were in a deplorable state. For example, those who indicated having computer laboratories, most of the computer laboratories found or reported in most schools were not so ideal to be computer laboratories. Most of them were converted from being classrooms, and therefore lacked most of the features that were specially made to store computers and other ICT facilities. Some of the prominent challenges these rooms had were lack of proper ventilation, lack of air conditioning, among others. As shown in Table 1, most facilities were generally rated poor with $333(94.0 \%)$, while good was rated at $21(5.9 \%)$ and excellent had $0(0.0 \%)$ rating.

The study also established that most schools had challenges of unavailable facilities for learners with special needs, and this challenge was attributed to the lack of investment by the Government, as discussed earlier in research question number three. It is worth noting that the scenario in Zambia's schools is similar that of most developing countries, where large numbers of people still lack access to basic infrastructure services, a condition that impedes a lot of development in the affected states. Therefore, the need for these countries to consider the role of infrastructure during the formulation and implementation of their goals to succeed the current sustainable development goals. As the absence of the appropriate support and information school IT infrastructure cannot deliver the processing power and networking facilities 
that learners need to enhance their skills and knowledge acquisition as a result of their exposure to ICT (Lockwood and Cornell, 2013; World Bank, 2012; Scott and Seth, 2012). The World Bank (2012) identifies infrastructure as being key for the transformational change if any nation must attain the expected economic growth and transition to more sustainable development pathways.

These findings reveal the root causes for some of the challenges that were highlighted regarding ICT investment in Zambia's secondary schools. The current scenario with regards to ICT investment framework raises concerns in line with the European Commission (2013) sentiments that the repercussions of ICT networks vary according to the way they are drawn on by isolated users as well as consortiums. The scenario in our Zambian education system, of not having a well-defined ICT investment framework disadvantages the country in the sense that, the 'differences' highlighted by the European Commission (2013) are what is responsible for the ICT divide in the productivity worldwide. The investment framework offers a stable direction to a particular entity in its endeavor to make decisions regarding investment in ICT. Not only that, the investment framework helps in deciding on critical aspects that require immediate or huge attention as an entity or state plans on their investments in relation with policy objectives and directives (European Commission, 2013).

\section{CONCLUSION}

The study established major challenges in investment in ICT in secondary schools, which included prolonged load shedding of power in most schools, which did not offer a conducive learning environment as most of the schools affected had no alternative power sources except the one provided by the Government through ZESCO. Apart from that, the challenge of inadequate infrastructure compromised the input, process and output to education, as this resulted in the congestion of pupils against one computer or not according an opportunity to other pupils to interact with technology, resulting in most of them not having an exposure to ICT. In this globalised world, this offers an unfair competition with other learners globally, who will have acquired qualification at similar levels of say Grade 12 and are expected to compete on the same platforms with others who have had a rich exposure to ICT.

The conversion of classrooms into computer rooms had its own effects on pupils, teachers as well as on ICT facilities. For example, the exposure of these facilities to heat and dust compromises the lifespan of these facilities as well as the quality of their output. Therefore, this study establishes why ICT facilities in some schools were breaking down more often as reported by some participants. Another conclusion is that some schools were literally incapable of maintaining and or repairing the available ICT facilities, hence the delay in availing the facilities to the teachers and pupils.Despite the challenges, this study establishes some opportunities in investment in ICT, such as schools becoming self-responsible in maintaining and repairing their own facilities if their capacity would allow. Such schools needed not wait for the time Government would be in a position to attend to their needs or work at the pace of the Government in repairing ICT facilities in the schools. This hence allows schools to attend to their needs promptly.

\section{RECOMMENDATIONS}

Based on the findings and the conclusion, the following recommendations were made:

1. The Ministry should strengthen the aspect of partnership, under the PPP approach, in investing in ICT, especially the infrastructure. Such investment should be done by allowing for innovative suggestions from other stakeholders and also sustain those ideas or input by actually partnering with the private sector on long term arrangements.

2. Stakeholders should be willing to partner and cooperate with Government in investing in ICT in schools and render their expertise to schools where they are given to operate. The cooperation of the private sector with the Government will help build the capacity of the schools for self-sustainability once their contract with Government is over and they transfer the ownership of the ICT facilities to schools.

\section{REFERENCES}

[1] Adeosun, O. (2010). Quality basic education development in Nigeria: Imperative for use of ICT. Journal of International Cooperation in Education, 13(2), 193-211.

[2] Adomi, E. E., \& Kpangban, E. (2010). Application of ICTs in Nigerian secondary schools. Library Philosophy and Practice (ejournal), 345.

[3] Afshari, M. (2012). Transformational leadership role of principals in implementing Information Communications Technology in Schools. Life science Journal, Vol. 9 (1).

[4] Akakandelwa, A., \& Munsanje, J. (2012). Provision of learning and teaching materials for pupils with visual impairment: Results from a national survey in Zambia. British Journal of Visual Impairment, 30(1), 42-49.

[5] Akbulut, Y. (2009). Investigating underlying components of the ICT Indicators measurement scale: The extended version. Journal of Educational Computing Research, 40(4), $405 \mathrm{e} 427$. http://dx.doi.org/10.2190/EC.40.4.b.

[6] Antonelli, Cristiano (1992). The Economics of Information Networks. Amsterdam: North- Holland.

[7] Bator, F. M. (1958). The anatomy of market failure. The Quarterly Journal of Economics, 72, 351-379.

[8] Benington, J. \& Moore, M. (2011). Public Value in Complex and Changing Times. In Public Value: Theory and Practice. 1-30. New York: Palgrave Macmillan.

[9] Benington, J. (2009). Creating the public in order to create public value?. Intl Journal of Public Administration, 32(3-4), 232-249.

[10] Bingimlas, K. A. (2009). Barriers to the successful integration of ICT in teaching and learning environments: A review of the literature. Eurasia Journal of Mathematics, Science \& Technology Education, 5(3), 235e245.

[11] Bleher, S. (2017). Mobile phones as an educational tool in subSaharan Africa: A comparison between Tanzanian and Zambian 
perceptions on mobile phone usage within secondary school education. Jönköping, Sweden: Jönköping University.

[12] Bryman A. (2016) Social research methods. Oxford, UK: Oxford University Press.

[13] Bryman, A. (2008). Social Research Methods. 3rd ed. Oxford, UK: Oxford University.

[14] Butcher, N. (2010). ICT, education, development, and the knowledge society. Kumasi, Ghana: GESCI Publisher, (281.29).

[15] Castillo, L. S. V. (2017). Call of Duty: A Case Study of ICT Integration in Philippine Provincial Public Schools in San Isidro Davao Oriental Post K-12 Implementation. Online Submission, 30, 1-16.

[16] Chaamwe, N. (2017). A Review on the Challenges that Hinder Sustainable Implementation of ICT as a subject in Rural Zambia. International Journal of Learning and Teaching, 3(3), 217-220.

[17] Chipeta, J. (2018). A Review of E-government Development in Africa A case of Zambia. Journal of E-Government Studies and Best Practices, 10, 13-19.

[18] Creswell J. W. (2009). Research Design: Qualitative, Quantitative, and Mixed Methods Approaches. London: SAGE Publications.

[19] Creswell J. W. (2012). Educational Research: Planning, Conducting, and Evaluating Quantitative and Qualitative Research. Boston: Pearson Education Inc.

[20] Creswell, J. W., \& Clark, K. L. P. (2007). Designing and conducting mixed methods Research. (2nd ed.). Thousand Oaks, CA: Stage Publications Inc.

[21] Creswell, J. W., \& Clark, V. L. P. (2017). Designing and conducting mixed methods research. Thousand Oaks, CA: Sage publications.

[22] Eligi, I., \& Mwantimwa, K. (2017). ICT accessibility and usability to support learning of visually-impaired students in Tanzania. International Journal of Education and Development using ICT, 13(2).

[23] European Commission. (2013). Survey of schools: ICT in education. https://ec.europa.eu/digital- agenda/node/51275. Retrieved on 8th April 2019.

[24] Gall, M. D., Borg, W. R., \& Gall, J. P. (1996). Educational research: An introduction. Longman Publishing.

[25] Gil-Flores, J., Rodríguez-Santero, J., \& Torres-Gordillo, J. J. (2017). Factors that explain the use of ICT in secondary-education classrooms: The role of teacher characteristics and school infrastructure. Computers in Human Behavior, 68, 441-449.

[26] Government of the Republic of Zambia (2010). Africa Peer Review Mechanism (APRM) Topics: Socio-Economic Development. GRZ: Lusaka.

[27] Government of the Republic of Zambia (2010). Information and Communication Technology (ICT) Strategic Plan 2011-2015. Lusaka: Ministry of Education.

[28] Hudson, H. (1997). 'Converging Technologies and Changing Realities: Toward Universal Access to Telecom in the Developing World' in Telecom Reform: Principles, Policies and Regulatory Practices, William Melody (Ed.). Technological University of Denmark. Chapter 26 pp 387-397. (Available online at http://www.lirne.net/resources/tr/chapter26.pdf) Retrieved 19th March, 2018.

[29] Hunjra A. I. (2012). Investment Appraisal Techniques and Constraints on Capital Investment (http://works.bepress.com/ahmed_hunjra/25)

[30] Isaacs I. (2007). Survey of ICT and Education in Africa. Zambia Country Report. Washington, D. C.: World Bank.

[31] Ishida, Y., Mwanza, P., Luchembe, M., Masaiti, G., \& Nsama, P. (2012). Scaling up Lesson Study in Urban and Rural Schools to Realize Sustainable, Inclusive Teacher Professional Development in Zambia. Journal of International Cooperation in Education, 2020 - cice.hiroshima-u.ac.jp

[32] Jain, P., \& Akakandelwa, A. (2016). Challenges of twenty-first century academic libraries in Africa. African Journal of Library, Archives \& Information Science, 26(2), 147.

[33] Jere, N.R., Thinyane, M., Boikhutso, T. \& Ndlovu, N. (2013). An assessment of ICT challenges in rural areas: ICT experts vs rural users views: a case of the Siyakhula Living Lab. In Proceedings of the South African Institute for Computer Scientists and Information Technologists Conference (pp. 233-241). East London, South Africa.

[34] Kakunta M. K., Simuyaba E., Haambokoma N. \& Mwewa G. (2020) Re-examining the Role of Teacher Trade Unions in Promotinh Welfare and Sustained Livelihood for their Members: A Case of Teacher Trade Unions in Lusaka, Zambia. International Journal of Research and Scientific Innovation in Social Sciences, Vol. IV, VIII, December, 2020.

[35] Kaminow, I.P., \& Li, T. (2002). Optical Fiber Telecommunication IVB: System Impairments. Academic Press, Califonia.

[36] Kangwa L. (2012). An Evaluation of the Extent to Which Information and Communication Technologies Have Been Integrated in the Teaching Process in Selected Colleges of Education in Zambia. Lusaka: UNZA.

[37] Kapembwa R., Simuyaba E., Njobvu T., Muleya G. \& Simui F. (2020) School Based Restorative Practices as Alternative to Punitive Practices in Influencing Positive Behaviour in Deviant Pupils in Zambia. International Journal of Education and Research, Vol 8, 12, December, 2020.

[38] Kavanagh, S. (2014). Defining and creating value for the public. Government Finance Review, 57-60.

[39] Khumalo, B., Molepo, G. \& Mji, A. (2015). Perceptions of school principals on the challenges arising from unavailability of information and communication technologies (ICT) in rural South African Schools. Proceedings of the Rethinking Teaching and Learning in the 21st Century. Manhattan Hotel Pretoria, South Africa, 21-23 September 2015 .

[40] Kinimäki, M., Vitanen, M., \&Vartra, M. (2003). Workplace bullying and the risk of cardiovascular disease and depression. Occup Environ Med, 60, 779-783.

[41] Koehler, M. J., \& Mishra, P. (2009). What is technological pedagogical content knowledge (TPACK)? Contemporary Issues in Technology and Teacher Education, 9(1), 60e70.

[42] Kozma, R. B. (2005). National policies that connect ICT-based education reform to economic and social development. Human Technology: An interdisciplinary journal on humans in ICT environments. 1, 117-156.

[43] Kreijns, K., Van Acker, F., Vermeulen, M., \& Van Buuren, H. (2013). What stimulates teachers to integrate ICT in their pedagogical practices? The use of digital learning materials in education. Computers in Human Behavior, 29(1), $217 \mathrm{e} 225$.

[44] Kukali, A. N. U. (2013). Opportunities and challenges for use and integration of information communication technology in management of public secondary schools in Bungoma South District, Kenya. International Journal of Science and Research (IJSR), India Online ISSN: 23197064, Volume 2 Issue 8.

[45] Lennon, M., \& Berg-Cross, G. (2010). Toward a high performing open government. Public Manager, 39(4), 33.

[46] Masaiti,G; Njobvu,T; \&.Kakupa, P. (2018). 'Education and Learning Post-Third Republic: Opportunities and Challenges' in Education in Zambia at 50 Years of Independence and Beyond: History, Current Status and Future Prospects, UNZA Press, Lusaka.

[47] Mdlongwa, T. (2012). Information and Communication Technology (ICT) as a Means of Enhancing Education in Schools in South Africa. Policy Brief, Africa Institute of South Africa.

[48] Meynhardt, T. (2009). Public value inside: What is public value creation?. Intl Journal of Public

[49] Ministry of Communications and Transport (2006). National information and communication technology policy. MCT: Lusaka. www.share4dev.info/kb/documents/3433.pdf retrieved 15th November 2016.

[50] Mulima O. (2013). The Perceptions of Teachers and Learners on the Role of ICTs in Teaching Religious Education in Zambia: A Case of Selected Secondary Schools in Kabwe District. Lusaka: University of Zambia.

[51] Mwendwa, N. K. (2017). Perception of teachers and principals on ICT integration in the primary school curriculum in Kitui County, Kenya. European Journal of Education Studies. 
N/0,,contentMDK:21608863 pagePK:141137 piPK:141127 theS itePK:293052,00.html.

[52] Ndibalema, P. (2014). Teachers' Attitudes towards the use of information communication technology (ICT) as a pedagogical tool in secondary schools in Tanzania: the case of Kondoa district. International Journal of Education and Research, 2(2), 116.

[53] Ndijuye, M. (2009). "Information and seeking behavior of pupils with visually impaired case study of Buigiri Primary School in Dodoma Region, Tanzania". Masters of Arts Dissertation, University of Dar es Salaam, Tanzania.

[54] Nkosha, C., Luchembe, M., \& Chakufyali, P. N. (2013). Girl-child education campaigns and enrolment/retention in Zambian basic schools: impact analysis. Journal of International Cooperation in Education, 15(3), 113-133.

[55] Nsama, Peggy (2008). Effects of Cost Sharing on Access to High School Education: in Kabwe Urban District of the Central Province, Zambia Paperback - Illustrated, April 25, 2013 (Masters Dissertation, University of Zambia).

[56] Nsama, Peggy, Masaiti, Gift, Akakandelwa, Akakandelwa (2020). Availability and Usage of Information Communication Technology Facilities in Secondary Schools in Zambia. Zambian Journal of Educational Management, Administration and Leadership (ZJEMAL) Vol. 1, No. 1

[57] Olibie, E. I., \&Akudolu, L. R. (2009). The roles of stakeholders in enhancing Information and Communication Technologies (ICT) use in secondary schools in Anambra State. Nigerian Journal of Curriculum Studies, 16(3), 244-252.

[58] Pazi, S. M. (2010). Cost-effective Information and Communication Technology (ICT) infrastructure for Tanzania (Doctoral dissertation, University of Sussex).

[59] Pelgrum, W. J., \& Voogt, J. (2009). School and teacher factors associated with frequency of ICT use by mathematics teachers. Country comparisons. Education and information technologies, 14(4), 293e308.
[60] Pelgrum, W.J. (2001). Obstacle to the integration of ICT in education: results from a worldwide educational assessment, Computers \& Education. 37, 163-178.

[61] Petko, D. (2012). Teachers' pedagogical beliefs and their use of digital media in classrooms: Sharpening the focus of the "will, skill, tool" model and integrating teachers' constructivist orientations. Computers \& Education, 58(4), 1351e1359. http://dx.doi.org/10.1016/j.compedu.2011.12.013.

[62] Phiri, W. (2016). Pupils' and teachers' perception toward the use of Information and Communication Technology (ICT) in the teaching and learning of Mathematics in selected secondary schools of Central Province, Zambia. International Journal of Multidisciplinary Research and Development, 3(1), 77-87.

[63] Ramaswami, R., \& Sivarajan, K. (2002) Optical Networks: A Practical Perspective 2nd Edition. Academic Press, Califonia.

[64] Relly, J.E. \& Sabharwal, M. (2009). "Perceptions of transparency of government policymaking: a cross-national study", Government Information Quarterly, Vol. 27, pp. 314-20.

[65] Rohatgi, A., Scherer, R., \& Hatlevik, O. E. (2016). The role of ICT self-efficacy for students' ICT use and their achievement in a computer and information literacy test. Computers \& Education. 102, 103e116. http://dx.doi.org/10.1016/j.compedu.2016.08.001.

[66] Scherer, R., Siddiq, F., \& Teo, T. (2015). Becoming more specific: Measuring and modeling teachers' perceived usefulness of ICT in the context of teaching and learning. Computers \& Education. 88, 202e214. http://dx.doi.org/10.1016/j.compedu.2015.05.005.

[67] Scott, A., \& Seth, P. (2012). Infrastructure services post-2015. London: ODI Research Report.

[68] Serpell, R. (2014). Promotion of Literacy in Sub-Saharan Africa: goals and prospects of CAPOLSA at the University of Zambia. Human Technology: An Interdisciplinary Journal on Humans in ICT Environments. Volume 10(1). 22-38.

[69] Shaikh, Z. A., \& Khoja, S. A. (2011). Role of ICT in Shaping the Future of Pakistani Higher Education System. Turkish Online Journal of Educational Technology-TOJET, 10(1), 149-161. 